P-ISSN: 2774-4574; E-ISSN: 2774-4582

TRILOGI, 2(3), September-Desember 2021 (266-269)

@2021 Lembaga Penerbitan, Penelitian, dan Pengabdian kepada Masyarakat (LP3M) Universitas Nurul Jadid Paiton Probolinggo

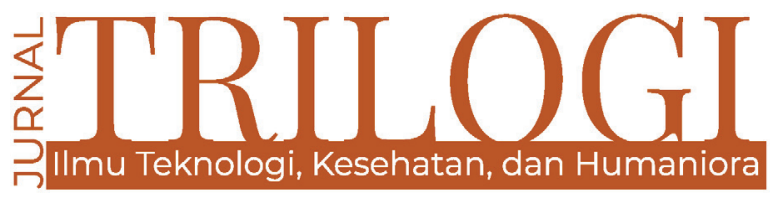

\title{
KLASIFIKASI PEMAHAMAN SANTRI DALAM PEMBELAJARAN KITAB KUNING MENGGUNAKAN ALGORITMA C4.5. ANALISIS POHON KEPUTUSAN (DECISION TREE) DI PESANTREN
}

\author{
Ahmad Hudawi AS \\ Universitas Nurul Jadid \\ ahmad.hudawi@unuja,ac,id

\section{Nur Octavia} \\ Universitas Nurul Jadid \\ vivioctavia071000@gmail.com
}

\section{Andik Elfandiono}

Universitas Nurul Jadid

andikeliyanto@gmail.com

Andi Bayu Setiawan

Universitas Nurul Jadid

riowck@gmail.com

\author{
Andik Elfandiono \\ Universitas Nurul Jadid \\ andikeliyanto@gmail.com
}

\author{
Alfian Abdul Ghafur \\ Universitas Nurul Jadid \\ alfyn84@gmail.com
}

\author{
Aldiniyah Eko Susanto \\ Universitas Nurul Jadid \\ aldiwoyy12@gmail.com
}

\begin{abstract}
Pesantren as the oldest Islamic educational institution in Indonesia has created the character formation of a nation characterized by akhlaq karimah that showing its ability to produce a cadre of scholars and to educate the nation's life. Education in Islamic boarding schools aims to deepen the knowledge of the Qur'an and the Sunnah of the Prophet. Pondok Pesantren Nurul Jadid Paiton Probolinggo is a boarding school educational institution founded by the late $\mathrm{KH}$. Zaini Mun'im in 1948 AD used a learning program with a traditional system of learning that focused on Islamic religious education with classical books. Now, Nurul Jadid Islamic Boarding School has been transformed into a modern Islamic boarding school that has a more comprehensive vision and mission. however, the classical treasures must be maintained, namely the understanding of classical books with formal education or what is commonly referred to as modern salafi pesantren. Based on this, the researcher wants to conduct a study related on how much students of the Nurul Jadid Islamic Boarding School can understand the classic books which are mandatory learning both in the dormitory and at school.

The classic book is a traditional book containing Islamic disciplines taught in Islamic boarding schools, from the structure of Arabic, Qur'an studies, hadith, aqidah, tasawuf/akhlaq, tafsir, figh to social and social sciences (mu'amalah). It is also called the bare book because it has no harakat (fathah, kasroh, dhammah, sukun). To read and understand the book, it takes a relatively
\end{abstract}


long time. This study aims to obtain a classification model from the classic book learning data at the Nurul Jadid Islamic boarding school. The method used in this study is the c4.5 algorithm decision tree. The results of the classification of the classic book learning data use attributes that have been classified based on their features and are iterated on cross validation so as to produce precise accuracy. Based on the results of testing with two methods, testing with the algorithm c4.5 algorithm the decision tree produces an accuracy of $80.61, \%$, for the $c 4.5$ algorithm decision tree (decision tree) and C4.5 and forward selection results in an accuracy of $85.68 \%$. There is an increase in accuracy with the addition of a selection feature.

Keywords: Data Mining, classification, c4.5 algorithm. decision tree, yellow book.

\begin{abstract}
Abstrak
Pesantren sebagai lembaga pendidikan Islam tertua di Indonesia memiliki pembentukan karakter bangsa yang bercirikan akhlakul karimah menunjukkan kemampuannya mencetak kader ulama dan serta mencerdaskan kehidupan bangsa. Pendidikan di pondok pesantren bertujuan untuk memperdalam ilmu al qur'an dan sunnah rasul, santri pondok pesantren belajar di sekolah tinggal di asrama yang disediakan oleh pesantren, satu dari diantara banyak Pesantren adalah Pesantren Nurul Jadid Paiton probolinggo, awal berdirinya Pondok Pesantren Nurul Jadid Paiton Probolinggo merupakan lembaga pendidikan pesantren yang didirikan oleh almarhum $\mathrm{KH}$. Zaini Mun'im pada tahun 1948 M. menggunakan program pembelajaran dengan tradisional sistem pembelajaran yang menitikberatkan pada pendidikan agama Islam dengan kitab-kitab klasik. Kini, Pesantren Nurul Jadid telah menjelma menjadi pondok pesantren modern yang memiliki lebih banyak visi dan misi yang komprehensif, namun demikian khazanah klasik yang harus dipelihara yaitu pemahaman kitab-kitab klasik dengan pendidikan formal atau yang biasa disebut dengan pesantren salafi modern. Berdasarkan hal tersebut, peneliti ingin melakukan kajian ingin mengetahui seberapa besar pemahaman santri Pondok Pesantren Nurul Jadid memahami kitabkitab kuning yang menjadi pembelajaran wajib baik di asrama maupun di sekolah.

Kitab kuning merupakan kitab tradisional yang mengandung diraasah islamiyah yang diajarakan pada pondok pesantren, mulai dari struktur bahasa arab (ilmu nahwu dan shorof), 'ulumul qur'an, hadits, aqidah, tasawuf/akhlaq, tafsir, figh dsampai ilmu sosial dan kemasyarakatan (mu'amalah). Disebut juga dengan kitab gundul karena tidak memiliki harakat (fathah, kasroh, dhammah, sukun) untuk bisa membaca dan memahami secara menyeluruh dibutuhkan waktu yang relatif lama. Penelitian ini bertujuan untuk mendapatkan model klasifikasi dari data pembelajaran kitab kuning di pondok pesantren Nurul Jadid. Metode yang digunakan dalam penelitian ini adalah algoritma c4.5. pohon keputusan (decision tree). Hasil dari klasifikasi data pembelajaran kitab kuning menggunakan atribut yang telah diklasifikasi berdasarkan fitur-fiturnya dan dilakukan iterasi pada cross validation sehingga menghasilkan akurasi yang tepat. Berdasarkan hasil pengujian dengan dua metode, pengujian dengan algoritma algoritma c4.5. pohon keputusan (decision tree) saja menghasilkan akurasi 80.61 , \%, untuk algoritma algoritma c4.5. pohon keputusan (decision tree) dan C4.5 dan foward selection menghasilkan akurasi 85.68\% . Terdapat peningkatan akurasi dengan penambahan fitur seleksi.
\end{abstract}

Kata kunci:Data Mining, klasifikasi, algoritma c4.5. pohon keputusan (decision tree), kitab kuning.

\section{Pendahuluan}

Dalam proses mengklasifikasi data training atau disebut juga data latih dibutuhkan untuk menentukan pola suatu data, pada data pembelajaran kitab kuning merupakan data pengalaman yang bisa digunakan pada algoritma klasifikasi. Sehingga algoritma klasifikasi dapat menggunkan data tersebut untuk mendapatkan pengetahuan serta menggolongkan pemahaman santri dalam pembelajaran kitab kuning berdasarkan parameter-parameter yang sudah ditentukan (Hidayat, 2017). Sebagai salah satu sarana dalam menentukan seorang santri dapat dikatakan paham dan atau tidak paham, pondok pesantren telah menentukan parameter yang harus dicapai oleh seorang calon santri sebelum memulai dan mengenal pembelajaran kitab kuning, antara lain parameter yang digunakan adalah sebagai berikut, kemampuan Tauhid, Fiqih, Nahwu, Shorrof, kelancaran dalam membaca alqur'an, imlaq (penulisan alqur'an), Tarikh Ke NU-an adalah kemampuan santri dalam pembelajaran kitab kuning serta memahami 
semua amaliyah yang dijalankan kalangan oleh nahdiyin NU. (Syafe'i, 2017)

Penelitian ini memberikan kontribusi yang positif terhadap perkembangan pondok pesantren khususnya Nurul Jadid dalam menentukan santri yang memenuhi kriteria, karena ditemukan banyak santri yang telah mengikuti proses pembelajaran selama 2 tahun akan tetapi belum dapat mengikuti proses pembelajaran kitab kuning dikarenakan kemampuan santri yag kurang dan background asal sekolah umum serta pendidikan orang tua mempengaruhi pemahaman santri dalam mengikuti pembelajaran kitab kuning. (Ja'far Amirudin, 2020)

\section{Metode}

Metode yang akan digunakan dalam penelitian ini untuk melakukan klasifikasi adalah dengan mencari data terkait pemahaman murid atau santri dalam mengkaji kitab kuning Pada Pondok Pesantren Nurul Jadid dengan menerapkan beberapa Model yaitu Forward selection dan Algorima C4.5, Data yang sudah didapat akan diseleksi atributnya dengan menggunaan forward selection sehingga akan menampilkan output berupa atribut-atribut yang mempunyai pengaruh yang signifikan terhadap dataset yang ada (Sofyan \& Stefanus Santosa , 2016). Selanjutnya untuk melakukan klasifikasi digunakanlah algoritma C4.5 untuk mengetahui klasifikasi santri terkait pembelajaran kitab kuning yang ada pada pondok pesantren Nurul Jadid, sedangkan untuk menguji dan mendapatkan hasil terkait kinerja dari algoritma C4.5 maka kita perlu mendapat crossvalidation dengan 10- fold, adapun langkalangka selanjutnya sebagai mana berikut ini:

1. Dalam hal mengelola data yang sudah didapat maka yang dilakukan adalah preprocessing yaitu memilah data, mencari atribut yang mempunyai pengaruh yang signifikan dan juga membersihkan noise yang ada pada data, adapun proses untuk mendapat atribut yang bisa digunakan untuk menentukan pengklasifikasian santri dalam memahami kitab kuning pada pondok pesantren nurul jadid adalah dengan melakukan foward selection dan juga missing value, dari proses tersebut sehingga didapatkan dataset santri baru yang dibisa dijadikan acuan dalam mentraining data dan testing data. (Ramdhani Khalid, 2020)

2. langkah selanjutnya adalah dengan melakukan uji terhadap dua model yaitu dengan data uji yang hanya menggunakan c4.5 dan juga dengan menggunakan C4.5 dengan forward selectionnya (Sitorus \& windarto, 2019)

3. Hasil dari uji tersebut kemudian akan dibandingkan dan akan menghasilkan output model dan tingkat akurasi dari dataset santri yang sudah diuji. (Mardi, 2019)

\section{Hasil dan Pembahasan}

Tujuan dari penelitian ini yaitu untuk meningkatkan nilai akurasi yang dihasilkan oleh algoritma klasifikasi naive bayes dengan mengurangi beberapa atribut pada dataset menggunakan algoritma fitur seleksi berupa forward selection dan menyeimbangkan data menggunakan algoritma adaboost. (Adzhal Arwani Mahfudh, 2019). Dataset diolah menggunakan perbandingan dari hasil yang didapatkan antara algoritma C4.5, dan C4.5 berbasis forward selection Perbandingan dari ketiga pengujian dapat dilihat pada tabel dibawah:

Figure 1. [1] Perbandingan akurasi

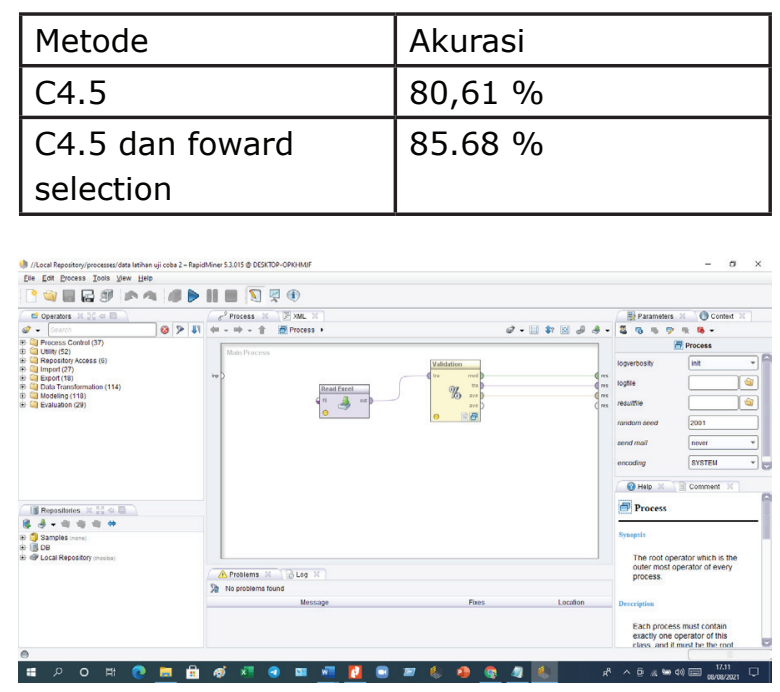

Fig. 1. Proses pengimplementasikan C4.5

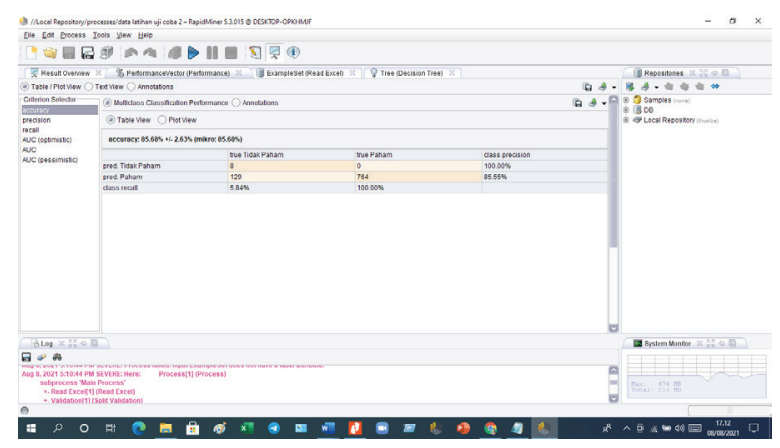

Fig. 2. Crossvalidation $\mathrm{C} 4.5$ 


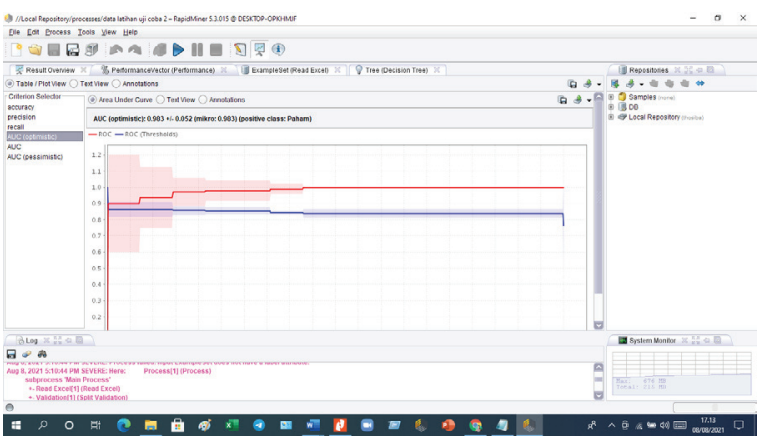

Fig. 3. AUC C4.5. (Dian Ardiansyah, 2018)

\section{Kesimpulan}

Kesimpulan yang didapatkan berdasarkan hasil penerapan algoritma $\mathrm{C} 4.5$ berbasis forward selection untuk klasifikasi pemahaman santri dalam pembelajran kitab kuning sebagai berikut:

1. Hasil pengujian dari kinerja algoritma C4.5 berbasis forward selection dengan 901 data menghasilkan akurasi lebih baik sebesar $85.68 \%$.

2. Penerapan forward selection sebagai metode seleksi fitur terukti bahwa metode tersebut dapat meningkatkan akurasi dari C4.5, dimana atribut yang terlibat semula pada dataset berkurang dengan hanya memilih atribut yang berpengaruh saja dan memperbaiki klasifikasi yang salah. (Arwanda \& Hannie, 2021)

\section{References}

Adzhal Arwani Mahfudh, H. M. (2019). Klasifikasi Pemahaman Santri Dalam Pembelajaran Kitab Kuning Menggunakan Algoritma Naive Bayes Berbasis Forward Selection. Walisongo Journal of Information Technology (wjit).
Arwanda, F. P., \& Hannie. (2021). Komparasi Penerapan Forward Selection Pada Algoritma C4.5 Dan Algoritma Naïve Bayes Untuk Memprediksi Kompetensi Karyawan. Jurnal Ilmiah Wahana Pendidikan.

Dian Ardiansyah, W. W. (2018). Algoritma C4.5 Untuk Klasifikasi Calon Peserta Lomba Cerdas Cermat Siswa Smp Dengan Menggunakan Aplikasi Rapid Miner. Jurnal Inkofar.

Hidayat, N. (2017). PEMERTAHANAN KEKHASAN PENGAJARAN KITAB KUNING PADA PONDOK PESANTREN DARUSSALAM MARTAPURA KALIMANTAN SELATAN (Telaah Aspek Linguistik dan Sosiolingustik). MADANIA.

Ja'far Amirudin, E. R. (2020). Implementasi Kurikulum Pesantren Salafi dan Pesantren Modern Dalam Meningkatkan Kemampuan Santri Membaca dan Memahami Kitab Kuning. Jurnal Pendidikan UNIGA.

Mardi, Y. (2019). Data Mining: Klasifikasi Menggunakan Algoritma C4.5. Jurnal Edik Informatika.

Ramdhani Khalid, K. E. (2020). Penerapan Direct Method Dalam Mempercepat Kemampuan Bahasa Arab Santri (Studi Kasus di Pondok Modern Nurussalam Karawang) . Indonesian Journal of Arabic Studies.

Sitorus, D. R., \& windarto, A. P. (2019). Penerapan Klasifikasi C4.5 Dalam Meningkatkan Sistem Pembelajaran Mahasiswa.

Sofyan, A., \& Stefanus Santosa . (2016). TEXT MINING UNTUK KLASIFIKASI PENGADUAN PADA SISTEM LAPOR MENGGUNAKAN METODE C4.5 BERBASIS FORWARD SELECTION. urnal Teknologi Informasi,.

Syafe'i, I. (2017). Pondok Pesantren Lembaga Pendidikan Pembentukan Karakter. Jurnal Pendidikan Islam. 